Jurnal Riset Kesehatan, 9 (1), 2020,33 - 38
DOI: $10.31983 /$ jrk.v9i1.5687
Jurnal Riset Kesehatan
http://ejournal.poltekkes-smg.ac.id/ojs/index.php/jrk

\title{
LIQUID CONSUMPTION, WORKLOADS AND HEAT STRESS WITH WORK FATIQUE
}

\author{
Diki Bima Prasetio ${ }^{a^{*}}$; Juni Arum Sari ${ }^{b}$ \\ a Departemen Keselamatan dan Kesehatan Kerja Fakultas Kesehatan Masyarakat Universitas \\ Muhammadiyah Semarang; Gedung Laboratorium Kesehatan Terpadu Lantai 4 UNIMUS; \\ Semarang 50273; Indonesia \\ b Unit Keselamatan dan Kesehatan Kerja Rumah Sakit Gigi dan Mulut Universitas \\ Muhammadiyah Semarang; Jalan Kedungmundu Raya No. 22; Semarang 50273; Indonesia
}

\begin{abstract}
Work fatigue is a form of body protection mechanism to avoid further damage and to recover after having a rest. Tire patch workers who work on the roadside are very vulnerable to work fatigue. The aim of this study is to determine the relationship between fluid consumption, workload and heat stress in one side and work fatigue on the other side. This type of research is observational with cross sectional approach. The samples of this research were 44 tire patch workers on the edge of Jalan Mugas Raya Semarang. Data analysis was performed with the Pearson Chi Square test. The results show that workers experienced high category of work fatigue by $50 \%$ and obtained a relationship between fluid consumption $(p=0.043)$, workload $(p=0.004)$, heat pressure $(p=0.033)$ and work fatigue. The conclusion is that the majority of workers who use tire patches on the roadside experience work fatigue, so they need to get health guidance.
\end{abstract}

Keywords: Fatigue, workload, heat stress

\section{Introduction}

Work fatigue affects workers' health and it decreases work productivity. Investigations from several countries show that work fatigue contributes $50 \%$ to workplace accidents (Tzeletopoulou A. et al, 2019; van Dam A, 2016). Based on data from the International Labor Organization (ILO), 1 worker dies every 15 seconds due to work accidents caused by work fatigue (International Labor Organization, 2013). The data reported by Badan Penyelenggara Jaminan Sosial Ketenagakerjaan show that in 2017 there were 123,041 such cases and in 2018 there were such 173,105 cases (Badan Penyelenggara Jaminan Sosial Ketenagakerjaan, 2019).

Work fatigue can cause discomfort which is indicated by a decrease in product quality, decreased speed of performance, increased errors and damage, loss of originality, decreased attention and inaccuracy in carrying out work,

\footnotetext{
*) Corresponding Author (Diki Bima Prasetio)

E-mail: dikibimaprasetio@unimus.ac.id
}

and frequent accidents due to work fatigue (Atiqoh J. et al, 2014). Work fatigue can come from various things such as monotonous works, individual factors --such as years of work and use of clothing while working--, environmental factors --such as heat stress, workers' mental and physicalcondition--, work intensity, psychological factors, diet, health status, as well as a history of illness. In addition, work fatigue can also be caused by work duration, work capacity and also the temperature of the workplace (Setyowati D. L. et al, 2014).

Another factor of work fatigue is that high ambient temperatures can result in increased body temperature. This will cause the hypothalamus tissue to stimulate the sweat glands so that sweat will come out of the body. The sweat contains various kinds of sodium chloride salt; the release of sodium chloride with sweat will reduce the levels in the body, so that it can inhibit the transportation of glucose as an energy source. This will cause a decrease in muscle contraction (Hall J, 2014). If the water 
that comes out of the body is not replaced with an adequate amount of fluid consumption, the body's cells will lose water. And this water loss is what causes dehydration (Tamsuri, 2009).

Water consumption consists of water that is consumed and obtained from food as a result of metabolism that comes out of the body including urine, water in feces, and water released through the skin and lungs (Sari, 2017). Fluid that is lost through sweat and is not replaced will decrease the plasma volume and also cause a decrease in physical and cognitive abilities of workers (Santoso, 2011). Workload is the length of time for someone to carry out activities according to his work capacity without showing signs of fatigue. If the workload is too heavy, it will affect somenone's performance (Hariono W, et al, 2009).

Heat stress is a limitation of the body receiving the heat load from a combination of the body that produces heat while doing work and environmental factors (such as exposure to ambient temperatures, humidity, air movement, and heat transfer radiation), heavy physical loads, insufficient rest periods, and clothing used (Horie S, 2013), (Wulandari K, 2016).

Previous researches have shown that there is a relationship between work fatigue and work productivity in the weaving labor in PT. Alkatex Tegal (Muizzudin A, 2013), and also a relationship between work fatigue and workplace accidents in car repair shop workers in Kendari City (Aswar E, et al, 2016). Research on labor in the Drilling Department of Pertamina EP Jambi has proven that there is a relationship between heat stress and feelings of work fatigue (Fahri S and Pasha E, 2010).

This study aims to determine the relationship between fluid consumption, workload and heat stress in one side and work fatigue on the other side in tire patch workers on the edge of Jalan Mugas Raya Semarang.

\section{Method}

This type of research is observational with cross-sectional approach. This study conducted observations and measurements of the variables at one particular point in time (Murti B, 2010). The samples in this study were 44 patch workers in the Mugas area on Jalan Tri Lomba Juang, Mugassari Subdistrict, Semarang Selatan District and all were made into samples. The study was conducted in August 2019. Independent variables in the study included liquid consumption, workload, and heat pressure. The dependent variable was work fatigue.

The primary data source was obtained after the tire patch workers agreed to be respondents by signing an informed consent. Primary data sources consisted of results of interviews by filling out questionnaires related to subjective work fatigue from the Industrial Fatigue Research Committee (IFRC) of the Japanese Association of Industrial Health. Other variables were also measured through interviews by filling out questionnaires related to fluid consumption, workload and heat pressure variables measured using a heat stress monitor Extech HT30 WVGT Meter. Data analysis used Pearson Chi Square test.

\section{Result and Discussion}

Table 1. Frequency distribution of research variables

\begin{tabular}{lrr}
\hline \multicolumn{1}{c}{ Variables } & f & \multicolumn{1}{c}{$\%$} \\
\hline Work Fatigue & & \\
Very high & 10 & 22,7 \\
High & 22 & 50,0 \\
Medium & 8 & 18,2 \\
Low & 4 & 9,1 \\
Fluid Consumption & & \\
$<2.8$ liters & 28 & 63,6 \\
$>2.8$ liters & 16 & 36,4 \\
Workload & & \\
$>100$ beats /minute & 37 & 84,1 \\
$<100$ beats /minute & 7 & 15,9 \\
Heat Stress & & \\
$>$ NAB & 35 & 79,5 \\
$<$ NAB & 9 & 20,5 \\
\hline
\end{tabular}

Most of the workers (22 people (50\%)) experienced the most fatigue in the high category. Patch workers who consumed $<2.8$ liters of fluid were 28 people $(63.6 \%)$, workloads with a pulse measurement $>100$ beats/minute were 37 people $(84.1 \%)$ and heat stress that exceeded NAB was experienced by 35 people (79.5\%) (Table 1).

In fluid consumption $<2.8$ liters with high work fatigue category of 15 people $(53.6 \%)$, there a relationship between fluid consumption with work discharge with a p-value of 0.043 (Table 2). Workers who work with high temperature work environments need to consume body fluids to replace the lost body fluids. Workers in hot work environments or heavy workloads require $>2.8$ liters/day of fluid consumption; whereas 
workers in jobs with no hot work environment or light workloads need 1.9 liters/day
(Perhimpunan Spesialis Kedokteran Okupasi Indonesia, 2014)

Table 2. The Relationship Between The Independent Variable and The Dependent Variable

\begin{tabular}{|c|c|c|c|c|c|c|c|c|c|}
\hline \multirow{3}{*}{ Variables } & \multicolumn{8}{|c|}{ Work Fatique } & \multirow{3}{*}{$p$} \\
\hline & \multicolumn{2}{|c|}{ Very High } & \multicolumn{2}{|c|}{ High } & \multicolumn{2}{|c|}{ Medium } & \multicolumn{2}{|c|}{ Low } & \\
\hline & $\mathbf{n}$ & $\%$ & $\mathbf{n}$ & $\%$ & $\mathbf{n}$ & $\%$ & $\mathbf{n}$ & $\%$ & \\
\hline \multicolumn{10}{|l|}{ Liquid Consumption } \\
\hline$<2,8$ liters & 9 & 32,1 & 15 & 53,6 & 3 & 10,7 & 1 & 3,6 & \multirow{2}{*}{0,043} \\
\hline$\geq 2,8$ liters & 1 & 63,1 & 7 & 43,8 & 5 & 31,3 & 3 & 18,8 & \\
\hline \multicolumn{10}{|l|}{ Workloads } \\
\hline$\geq 100$ beats $/$ minutes & 9 & 24,3 & 21 & 56,8 & 6 & 16,2 & 1 & 2,7 & \multirow{2}{*}{0,004} \\
\hline$<100$ beats/minutes & 1 & 14,3 & 1 & 14,3 & 2 & 28,6 & 3 & 42,9 & \\
\hline \multicolumn{10}{|l|}{ Heat Stress } \\
\hline$\geq \mathrm{NAB}$ & 9 & 25,7 & 19 & 54,3 & 6 & 17,1 & 1 & 2,9 & \multirow{2}{*}{0,033} \\
\hline$<\mathrm{NAB}$ & 1 & 11,1 & 3 & 33,3 & 2 & 22,2 & 3 & 33,3 & \\
\hline
\end{tabular}

Fluid consumption can have a positive effect to prevent work fatigue, especially workers in work environments with hot-pressure work conditions (Jamaludin J, et al, 2012). Workers at work are expected to consume as many as 11 small glasses $(1$ cup $=250 \mathrm{ml})$ or as much as 2.8 liters per day every 20-30 minutes both when thirsty and not thirsty to prevent dehydration which will result in work fatigue (Sari M.P, 2017). Water is one of the vital elements needed by the body. Consumption of fluids can improve the main function of blood and other bodily functions of fluids. Lack of fluid consumption can cause fatigue. This is because the body experiences mild dehydration which makes the blood thicken and the heart work harder (Perez-Gonzalez A, et al, 2012).

Water has functions in various important processes in the human body, such as regulating body temperature, forming cells and body fluids, as solvents and lubricants and as bearings, and as media elimination of metabolic waste (Hastuti Y.D, et al, 2015). Fluid consumption is needed by the body because water has many functions needed by the body as a medium of transportation, regulating body temperature, forming cells and body fluids and as a solvent. About $80 \%$ of individual needs are contributed by liquids including water, and the rest is obtained from food. Each individual's fluid needs is influenced by various factors such as age, sex, activity level, environmental factors, and nutritional status (normal, overweight, obesity). The body normally loses water through the lungs when exhaling, through sweat, urine production and during bowel movements. The loss of fluid must be replaced to keep the condition and function of body fluids undisturbed (Aprillia D.D, et al, 2014).
Research conducted on blacksmith workers shows that there is a relationship between drinking water consumption and subjective complaints of dehydration due to heat stress (Hidayat R.A, 2016). The habit of drinking water that is not done in a period of time often still allows dehydration, even though the amount is sufficient. Physiologically, humans are equipped with a response to enter fluids into the body. The thirst response is a reflex that automatically becomes a command to the body to enter fluids (Indra, et al, 2013).

Workloads > 100 beats/minute category high workload was experienced by 21 people $(56.8 \%)$. There is a relationship between workload and work fatigue with a p-value of 0.004 (Table 2). Workload is a number of activities that must be completed by a person or group of people over a certain period of time with a certain speed and volume of work and under normal circumstances (Rambulangi C.J, 2016). Workload is divided into 2 namely physical workload and mental workload. Patchwork work tends to have a greater physical workload than mental workload (Maharja R, 2015). Workload is influenced by 2 factors: internal factors (somatic factors and psychological factors) and external factors (organizational tasks, work environment and workplace hazard factors). Workloads that cause physical activity can affect fatigue (Tarwaka, 2010).

Work processes that involve physical activity will increase the pulse along with an increase in workload coupled with a long work duration and monotonous work. They can cause fatigue in the body (Kusgiyanto W, et al, 2017). Physical fatigue occurs due to increased workload resulting in increased oxygen 
consumption. The maximum point of oxygen consumption will reduce the supply of oxygen to the muscle resulting in the breakdown of muscle glycogen into energy and lactic acid. Lactic acid will accumulate so that the muscles become swollen and contracted. This is a symptom of fatigue (Maharja R, 2015)

Excessive workload can cause effects such as physical and mental fatigue, irritability, headaches and digestive disorders. The workload that is too little such as lack of movement can cause boredom. Boredom in routine daily work can result in a lack of employee attention to work so that it can reduce employee performance (Wulandari S, et al, 2017). If the workload is too heavy, it will affect its performance.13 The results of previous studies indicated a relationship between the weight of the load and work fatigue in transport workers (Hariono W, et al, 2009).

The heat pressure exceeds (NAB) category of high work fatigue was experienced by 19 people $(54.3 \%)$. There is a relationship between heat pressure and work fatigue with a p-value of 0.033 (Table 2). Heat pressure can affect bodily functions such as heart rate and pulse, blood pressure, power of concentration and physical endurance of living things. The higher the heat pressure, the faster the body will experience fatigue (Lestari D.T, et al, 2018).

If the physical environment at work is too hot, it can cause the workforce to get tired quickly due to a lot of fluid and salt loss. When the production of heat in the environment is not balanced with the production of heat released by the body, it will produce uncomfortable working conditions (Margaretha, et al, 2019)

Exposure to high temperatures can cause the hypothalamus to stimulate the sweat glands to sweat as a form of response to the state of the surrounding environment, thereby causing a reduction in fluid in the body which causes thirst, fatigue and dehydration. The skin has many functions which are useful in maintaining body homeostasis. These functions can be divided into functions of protection, absorption, excretion, perception, regulation of body temperature (thermoregulation), and formation of vitamin D. Although the stratum corneum is waterproof, about $400 \mathrm{~mL}$ of water can come out by evaporating through the sweat glands every day (Nofianti D.W, et al, 2019).

A person working indoors excretes $200 \mathrm{~mL}$ of additional sweat, and active people will excrete more. Apart from releasing water and heat, sweat is also a means to excrete salt. Hydration status is influenced by the presence of high ambient temperature factors resulting in increased expenditure of fluids through breathing and perspiration which cause the need for increased body fluids and adequate fluid consumption according to the needs (Bates G.P, et al, 2010) (Veronica S, et al, 2010). This is in line with research conducted in the industry on male workers working in the work environment with heat pressure exceeding NAB. As much as $52 \%$ of workers are dehydrated (Andayani $\mathrm{K}$ and Dieny F.F, 2013). The results of this study are consistent with previous research which proves that there is a significant relationship between heat stress and labor fatigue in the Drilling Section of Pertamina EP Jambi (Fahri S and Pasha E, 2010).

\section{Conclusion and Sugestion}

Most of the tire patch workers in the Mugas area of Semarang experience work fatigue. This can be caused by fluid consumption, workload and heat stress. In this research, there has not been an analysis of the relationship of other factors originating from individuals and measurements related to hazardous factors in other work environments. The results of this study are expected to be a reference to public health actions in fostering the safety and health of informal sector workers.

\section{Acknowledgements}

Thanks to the research team, tire patch workers on the Mugas Semarang road and all parties involving in and assisting the research.

\section{References}

Andayani K., dan Dieny F.F., (2013), Hubungan Konsumsi Cairan dengan Status Hidrasi pada Pekerja Industri Laki-Laki. Journal of Nutrition College, 2(4), 622-629.

Aprillia D.D., dan Khomsan A., (2014), Konsumsi Air Putih, Status Gizi, dan Status Kesehatan Penghuni Panti Werda di Kabupaten Pacitan. Jurnal Gizi Pangan, 9(3), 167-172.

Aswar E., Asfian P., Fachlevy A. F., (2016) Faktor-Faktor yang Berhubungan dengan Kecelakaan Kerja pada Pekerja Bengkel Mobil Kota Kendari Tahun 2016, Jurnal Ilmiah Mahasiswa Kesehatan Masyarakat, $\quad$ 1(3), doi:http://dx.doi.org/10.37887/jimkesm as.v1i3 
Atiqoh J., Wahyuni I., and Lestantyo D., (2014), Faktor-Faktor yang Berhubungan dengan Kelelahan Kerja pada Pekerja Konveksi Bagian Penjahitan di CV. Aneka Garment Gunungpati Semarang," Jurnal Kesehatan Masyarakat, 2(2), 119-126

Badan Penyelenggara Jaminan Sosial Ketenagakerjaan. (2019). Angka Kecelakaan Kerja Cenderung Meningkat, BPJS Ketenagakerjaan Bayar Santunan Rp1,2 Triliun. Link:https:// www.bpjsketenagakerjaan. go.id/berita/23322/Angka-KecelakaanKerja-Cenderung-Meningkat,-BPJS-Kete nagakerjaan-Bayar-Santunan-Rp1,2-Trili un

Bates G.P., Veronica S., Miller, Joubert D.M., (2010), Hydration Status of Expatriate Manual Workers During Summer in the Middle East, The Annals of Occupational Hygiene, 54(2), 137-143, doi:10.1093/annhyg/mep076

Fahri S., Pasha E., (2010), Kebisingan dan Tekanan Panas dengan Perasaan Kelelahan Kerja pada Tenaga Kerja Bagian Drilling Pertamina EP Jambi, Proceedings seminar nasional kesehatan masyarakat, olahraga, gizi, dan pangan. Universitas Muhammadiyah Semarang, 128-136

Hall J., (2014), Buku Ajar Fisiologi Kedokteran, Edisi 12, Singapore: Elsevier Pte Ltd

Hariono W., Suryani D., Wulandari Y., (2009), Hubungan Antara Beban Kerja, Stres Kerja, dan Tingkat konflik dengan Keleahan Kerja Perawat di Rumah Sakit Islam Yogyakarta PDHI Kota Yogyakarta. Jurnal KES MAS UAD, 3(3), 186-197

Hastuti Y.D., Nasution E., Aritonang E., (2015), Perilaku Konsumsi Air Minum Pada Siswa/Siswi SMA Negeri Medan Tahun 2015. Jurnal Kesehatan Masyarakat, 1(2), $1-6$.

Hidayat, R.A. (2016). Hubungan Konsumsi Air Minum Dengan Keluhan Subjektif Akibat Tekanan Panas pada Pekerja Pandai Besi Di Desa Bantaran Probolinggo. Jurnal Keperawatan Muhammadiyah, 1(1), 32-43.

Horie S., (2013), Prevention of Musculoskeletal Disorders in the Workplace. Journal of Japan Medical Association, 56(3), 186-192.

Indra, Naiem M.F., Wahyuni A., (2013), Determinan Keluhan Akibat Tekanan Panas Pada Pekerja Bagian Dapur
Rumah Sakit di Kota Makassar. Journal of Chemical Information and Modeling, 53(9), 1689-1699.

International Labour Organization. (2013). Keselamatan dan Kesehatan Kerja: Sarana untuk Produktivitas. Jakarta: International Labour Organization Jakarta

Jamaludin J., Lestantyo D., Wahyuni I., (2012), Kelelahan Pada Pekerja Bagian Pengepakan di PT. X Semarang, Media Kesehatan Masyarakat Indonesia, 11(1), 25-33.

doi:https://doi.org/10.14710/mkmi.11.1 .25-33

Kusgiyanto W., Suroto S., dan Ekawati E., (2017), Analisis Hubungan Beban Kerja Fisik, Masa Kerja, Usia, Dan Jenis Kelamin Terhadap Tingkat Kelelahan Kerja Pada Pekerja Bagian Pembuatan Kulit Lumpia Di Kelurahan Kranggan Kecamatan Semarang Tengah, Jurnal Kesehatan Masyarakat, 5(5), 413-423

Lestari D.T., Raharjo M., Yunita N.A., (2018), Hubungan Paparan Panas Dengan Tekanan Darah Pada Pekerja Pabrik Baja Lembaran Panas, Jurnal Kesehatan Masyarakat, 6(6), 79-86

Maharja R., (2015), Analisis Tingkat Kelelahan Kerja Berdasarkan Beban Kerja Fisik Perawat Di Instalasi Rawat Inap Rsu Haji Surabaya. The Indonesian Journal of Occupational Safety and Health, 4(1), 93-102.

doi:http://dx.doi.org/10.20473/ijosh.v4i 1.2015.93-102

Margaretha, Thohari. I., Marlik, (2019), Pengaruh Tekanan Panas Terhadap Kelelahan Pekerja, GEMA Lingkungan Kesehatan, 17(2), 105-109

Muizzudin A., (2013), Hubungan Kelelahan dengan Produktivitas Kerja pada Pekerja Tenun di PT. Alkatex Tegal. Unnes Journal of Public Health, 2(4), 1-8.

Murti B., (2010), Desain dan ukuran sampel untuk penelitian kuantitatif dan kualitatif di bidang kesehatan. Yogyakarta, Gadjah Mada University Press

Nofianti D. W., Koesyanto H., Masa Kerja, Beban Kerja, Konsumsi Air Minum dan Status Kesehatan dengan Regangan Panas pada Pekerja Area Kerja, Higeia Journal Of Public Health Research And Development, 3(4), 524-533, doi:https://doi.org/10.15294/higeia/v3i 


\section{$4 / 28158$}

Perez-Gonzalez A., Urtiaga A.M., Ibanez R., Ortiz I., (2012), State of the art and review on the treatment technologies of water reverse osmosis concentrates, Water Research, 46(2), 267-283. doi:https://doi.org/10.1016/j.watres.201 1.10 .046

Perhimpunan Spesialis Kedokteran Okupasi Indonesia. (2014). Pedoman Kebutuhan Cairan Bagi Pekerja Agar Tetap Sehat Dan Produktif. Jakarta, Kementerian Kesehatan RI.

Rambulangi C.J., (2016), Hubungan Antara Beban Kerja Dengan Kelelahan Kerja Pegawai Badan Pertanahan Nasional Tingkat II Samarinda. Psikoborneo, 4(2), 292-300.

Santoso B. I., (2011), Air Bagi Kesehatan. Jakarta: Centra Communications.

Sari M. P., (2017), Iklim Kerja Panas dan Konsumsi Air Minum Saat Kerja Terhadap Dehidrasi. HIGEIA (Journal of Public Health Research and Development), 1(2), 108-118

Sari N. P., (2014), Pengaruh Iklim Kerja Panas Terhadap Dehidrasi dan Kelelahan Pada Tenaga Kerja Bagian Boiler di PT. Albasia Sejahtera Mandiri Kabupaten Semarang. Journal of Nutrition College, 5(6): 12-20.

Setyowati D. L., Shaluhiyah Z., Widjasena B., (2014), Penyebab Kelelahan Kerja pada Pekerja Mebel. Jurnal Kesehatan Masyarakat Nasional, 8 (8), 386-392, doi:http://dx.doi.org/10.21109/kesmas. v8i8.409
Tamsuri, A., (2009), Klien Gangguan Keseimbangan Cairan dan Elektrolit. Edisi 1, Jakarta EGC.

Tarwaka, (2010), Ergonomi Industri: Dasar-Dasar Pengetahuan Ergonomi Dan Aplikasi Di Tempat Kerja. Solo, Harapan Press.

Tzeletopoulou A., Alikari V., Krikelis M. I., Zyga S., Tsironi M., Lavdaniti M., Theofilou P., (2019), Fatigue and perceived social support as predictive factors for aggressive behaviors among mental healthcare professionals. Archives of Hellenic Medicine, 36(6), 792-799

van Dam A., (2016), Subgroup Analysis in Burnout: Relations Between Fatigue, Anxiety, and Depression. Front Psychol. 7:90. doi: 10.3389 /fpsyg. 2016.00090

Veronica S., Bates G.P., Miller, (2010), Hydration, Hydration, Hydration, The Annals of Occupational Hygiene, 54(2), 134-136, doi:10.1093/annhyg/mep091

Wulandari K., Widjasena B., Ekawati., (2016), Hubungan Beban Kerja Fisik Manual dan Iklim Kerja Terhadap Kelelahan Pekerja Konstruksi Bagian Project Renovasi Workshop Mekanik. Jurnal Kesehatan Masyarakat, 4(3), 425-435.

Wulandari, S., Samsir S., Marpaung R.J.M., (2017), Analisis Beban Kerja Mental, Fisik Serta Stres Kerja Pada Perawat Secara Ergonomi Di RSUD Dr. Achmad Mochtar Bukittinggi, Jurnal Online Mahasiswa Fakultas Ekonomi Universitas Riau. 4(1), 954-966 